\title{
The prevalence and causes of low vision and blindness amongst learners at the Akropong School for the Blind in Ghana
}

\begin{tabular}{|c|c|}
\hline \multicolumn{2}{|c|}{$\begin{array}{l}\text { Authors: } \\
\text { Michael A. Kwarteng }{ }^{1,2} \text { (D) } \\
\text { Khathutshelo P. Mashige } \\
\text { Kovin S. Naidoo } \\
\text { Samuel B. Boadi-Kusi } \\
\text { Pirindhavellie Govender- } \\
\text { Poonsamy }\end{array}$} \\
\hline $\begin{array}{l}\text { Affiliations: } \\
{ }^{1} \text { Department } \\
\text { Faculty of Scie } \\
\text { Engineering, B } \\
\text { University of S } \\
\text { Education, Bin } \\
\text { Zimbabwe }\end{array}$ & $\begin{array}{l}\text { Optometry, } \\
\text { nce and } \\
\text { indura } \\
\text { cience } \\
\text { dura, }\end{array}$ \\
\hline $\begin{array}{l}{ }^{2} \text { Discipline of } \\
\text { College of Hea } \\
\text { University of } \\
\text { Durban, South }\end{array}$ & $\begin{array}{l}\text { Optometry, } \\
\text { lth Sciences, } \\
\text { waZulu-Natal, } \\
\text { Africa }\end{array}$ \\
\hline $\begin{array}{l}{ }^{3} \text { Department } \\
\text { and Vision Sci } \\
\text { Allied Health } \\
\text { University of } \\
\text { Cape Coast, G }\end{array}$ & $\begin{array}{l}\text { Optometry } \\
\text { ence, School of } \\
\text { iciences, } \\
\text { Cape Coast, } \\
\text { hana }\end{array}$ \\
\hline $\begin{array}{l}\text { Correspondin } \\
\text { Michael Kwart } \\
\text { kwartengmich } \\
\text { gmail.com }\end{array}$ & $\begin{array}{l}\text { g author: } \\
\text { eng, } \\
\text { aelagyemang@ }\end{array}$ \\
\hline $\begin{array}{l}\text { Dates: } \\
\text { Received: } 27 \mathrm{~S} \\
\text { Accepted: } 03 \\
\text { Published: } 22\end{array}$ & $\begin{array}{l}\text { ept. } 2020 \\
\text { Mar. } 2021 \\
\text { Apr. } 2021\end{array}$ \\
\hline $\begin{array}{l}\text { How to cite th } \\
\text { Kwarteng MA, } \\
\text { Naidoo KS, Bo } \\
\text { Govender-Poo } \\
\text { prevalence an } \\
\text { vision and blin } \\
\text { learners at the } \\
\text { School for the } \\
\text { Afr Vision Eye } \\
2021 ; 80(1) \text {, a6 } \\
\text { org/10.4102/a }\end{array}$ & $\begin{array}{l}\text { is article: } \\
\text { Mashige KP, } \\
\text { adi-Kusi SB, } \\
\text { nsamy P. The } \\
\text { d causes of low } \\
\text { dness amongst } \\
\text { Akropong } \\
\text { Blind in Ghana. } \\
\text { Health. } \\
\text { 11. https://doi. } \\
\text { Iveh.v80i1.611 }\end{array}$ \\
\hline $\begin{array}{l}\text { Copyright: } \\
\text { C 2021. The A } \\
\text { Licensee: AOS } \\
\text { is licensed unc } \\
\text { Creative Comr } \\
\text { Attribution Lic }\end{array}$ & $\begin{array}{l}\text { uthor(s). } \\
\text { IS. This work } \\
\text { der the } \\
\text { nons } \\
\text { ense. }\end{array}$ \\
\hline Read online: & \\
\hline 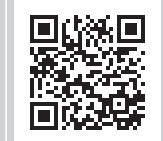 & $\begin{array}{l}\text { Scan this QR } \\
\text { code with your } \\
\text { smart phone or } \\
\text { mobile device } \\
\text { to read online. }\end{array}$ \\
\hline
\end{tabular}

Background: Low vision and blindness have significant implications, resulting in a generally reduced quality of life amongst the sufferers.

Aim: To determine the prevalence and causes of low vision and blindness amongst learners at the Akropong School for the Blind.

Setting: The study was conducted in Akropong School for the Blind, Ghana.

Methods: A cross-sectional study design was used. Eye examinations included measurements of presenting distance visual acuity (PDVA) with the Tumbling ' $\mathrm{E}^{\prime}$ distance LogMAR chart. Anterior and posterior segments were examined with an ophthalmoscope and a slit lamp.

Results: Two hundred and sixty-eight $(N=268)$ learners comprising $157(58.6 \%)$ males and 111 $(41.4 \%)$ females took part in this study and their ages ranged from 4 to 43 years (mean and standard deviation $[\mathrm{SD}]=15.79 \pm 6.15$ years). The results indicated that $76.1 \%$ were classified as blind and $23.9 \%$ of the learners had low vision. The leading cause of low vision was glaucoma (39.1\%) followed by pseudophakia (21.9\%) and retinopathy (18.8\%). The most common causes of low vision and blindness based on pathology found on ocular anatomical structures were corneal opacity/phthisis bulbi (35.5\%), followed by glaucoma (25\%), cataract (13.4\%) and retinopathy $(10.8 \%)$.

Conclusion: The leading causes of low vision and blindness identified in this study were because of avoidable diseases such as corneal opacity/phthisis bulbi and glaucoma. This highlighted the need for adequate primary eye care services, equitable eye health workforce distribution and eye health awareness in Ghana to help prevent low vision and blindness.

Keywords: prevalence; low vision; blindness; Ghana; School for the Blind.

\section{Introduction}

Optometrists are eye care providers who provide comprehensive eye and vision care services, including vision rehabilitation to the visually impaired. ${ }^{1}$ These services are limited in developing countries such as Ghana because of the limited eye health workforce, which may result in a high prevalence of undetected visual problems and consequently, visual impairment. ${ }^{2}$ Visual impairment contributes to poor academic performance amongst children in developing countries and as such, about $90 \%$ of children with blindness do not attend school. ${ }^{3}$

The World Health Organization $(\mathrm{WHO})^{4}$ defines blindness as:

[T] he inability to perceive light in the better eye and low vision refers to reduced visual functioning after standard refractive correction with visual acuity of worse than $6 / 18$ to light perception, or a visual field of less than ten degrees from the point of fixation in the better eye.

To achieve the goal of eliminating avoidable blindness and visual impairment, periodic estimates on the causes of vision impairment are essential as the causes vary with geographical location and time. ${ }^{4}$ The data may then be used in developing policies for eliminating visual impairment and also to initiate future eye care planning.

With this in mind, the Ghana National Blindness and Visual Impairment Study under the auspices of the Operation Eyesight Universal was conducted from February 2015 to November 2016. ${ }^{5}$ This population-based study aimed at providing a comprehensive representation of national data on 
blindness and visual impairment in Ghana. The study identified the prevalence of moderate and severe low vision to be $1.07 \%$ and blindness to be $0.74 \%$ in the general population. ${ }^{5}$ The causes of low vision and blindness, especially in children, were not included in the study, revealing a gap in the research.

There are currently three Schools for the Blind in Ghana: Wa Methodist School located in the Upper West Region of Northern Ghana, Akropong School located in Southern Ghana and Wenchi Methodist Secondary School located in the Brong-Ahafo region of Central Ghana (enrols both visually impaired and sighted students). ${ }^{6}$ Akafo and Hagan, ${ }^{7}$ and Ntim-Amponsah and Amoaku ${ }^{8}$ conducted surveys in Akropong School for the Blind to determine the causes of childhood visual impairment and blindness in 1989 and 2003, respectively. The study by Akafo and Hagan ${ }^{7}$ reported that $80 \%$ of the 129 children examined were blind, with corneal opacity/phthisis bulbi, cataracts, glaucoma and chorioretinal disease being the major causes of blindness. The study by Ntim-Amponsah and $\mathrm{Amoaku}^{7}$ reported that over $40 \%$ of the children had low vision and identified corneal diseases and cataracts as the major causes of blindness. However, both studies did not provide sufficient data on the causes of visual impairment amongst the children in this School for the Blind. In addition, the authors ${ }^{7,8}$ based their diagnoses only on ocular structures affected and not the specific pathology on the structures. Furthermore, these studies at Akropong School for the Blind were conducted almost two decades ago.

The most recently published study on visual impairment in children in Ghana is a survey conducted in 2017 at Wa Methodist School for the Blind, ${ }^{6}$ located in Northern Ghana. This study reported that the prevalence of low vision and blindness was $67 \%$ and 33\%, respectively. Regional inequality in human development (education and health) is substantial in Ghana, with the northern regions massively disadvantaged, particularly in terms of medical services compared to the southern regions. ${ }^{9}$ These regional disparities may affect the health and eye profiles of children in the different regions of Ghana. With more recent information, a pattern of changes in low vision and blindness of the learners in the school can be identified. The aim of this study was, therefore, to determine the prevalence and causes of low vision and blindness amongst the learners in Akropong School for the Blind to assess the need for services and to compare the results with other studies.

\section{Methods}

A cross-sectional study design was used to determine the prevalence and causes of low vision and blindness amongst learners at the Akropong School for the Blind in Ghana, which is situated in South Ghana. Akropong School for the Blind is a mixed school with day and boarding learners and caters to learners from kindergarten, primary, junior high school and vocational departments. The school admits learners with blindness and the visually impaired. All 375 learners enrolled in the school in 2019 were included in the study sample using a purposive sampling approach.

\section{Data collection}

A structured questionnaire was used to collect demographic data such as the age and gender of the participants. To complete the eye examination, a clinical form specifically designed for this study was used to record distance and near visual acuities and causes of low vision and blindness.

Visual acuity (VA) was measured with the Tumbling ' $E$ ' distance $\log$ MAR chart at a distance of four metres. The VA was recorded and classified according to the WHO classification of low vision and blindness (Table 1). For the purpose of this study, blindness was defined as no perception of light (NPL) and light perception (PL) in the better eye and low vision as VA worse than $6 / 18$ to perception of light with residual vision. The examination of the anterior segment was performed using a slit lamp biomicroscope. Assessment of the posterior segment was conducted with an ophthalmoscope and slit lamp biomicroscope, using a $90 \mathrm{D}$ diagnostic lens through a dilated pupil. The causes of low vision and blindness were identified based on pathology found for ocular anatomical structures.

\section{Data analysis}

Data collected were analysed using the International Business Machines Corporation's Statistical Package for Social Sciences (IBM SPSS) version 21 (SPSS Inc, Chicago, IL, United States [US]). Descriptive analysis of ranges of VA, measures of central tendency for age and frequencies for gender were performed and the prevalence rates of low vision and blindness were determined. A Pearson chi-square test was used to determine associations amongst the proportion of age groups and causes of low vision and blindness.

\section{Ethical considerations}

The study was approved by the Ghana Health Service Ethical Review Committee (Protocol identity number: GHS-ERC: 017/08/18) and the Biomedical Research Ethics Committee of the University of KwaZulu-Natal (reference: BE 688/18). The study adhered to the tenets of the Declaration of Helsinki involving human subjects. Informed assent and consent were obtained from each learner and their parents and/or guardians, respectively, after the nature of the study was explained. There were no risks and/or discomfort associated with participating in the study and no financial remunerations were offered to the learners. Participation in the study was voluntary and learners were informed that they could

Table 1: WHO classification of low vision and blindness according to VA ${ }^{8}$

\begin{tabular}{lll}
\hline Classification & Type & Visual acuity in logMAR \\
\hline Low vision & Moderate low vision & $0.52-1.00$ \\
& Severe low vision & $1.02-1.30$ \\
& Profound low vision & $1.32-1.80$ \\
Blindness & Near-total blindness & $1.82-3.00$ \\
& Total blindness & 4.0 (NPL) \\
\hline
\end{tabular}

Source: Kumah EK, Wiafe B, Baffoe IO. Ghana national blindness and visual impairment study [homepage on the Internet]. 2017 [cited 2018 Feb 2]. Available from: https://www.iapb.org/ wp-content/uploads/2020/09/Ghana-Study-BVIS-8 6_2017_-Final-edit.pdf

NPL, no perception of light; logMAR, Logarithm of the Minimum Angle of Resolution. 
withdraw their participation at any point without facing any penalties or losing treatment or other benefits to which they would usually be entitled.

\section{Results}

\section{Demographics}

Two hundred and sixty-eight of the 375 learners participated in the study, resulting in a response rate of $71.5 \%$. Their ages ranged from 4 to 43 years (mean age and standard deviation $[S D]=15.79 \pm 6.15$ years). More than half of the participants (58.6\%) were males and $41.4 \%$ were females.

\section{Prevalence of low vision and blindness in the better eye}

Two hundred and four (76.1\%) participants were classified as blind. The prevalence of low vision was $23.9 \%$ (64 participants) (95\% confidence interval [CI]: 18.8-29.0). Table 2 shows the

TABLE 2: Prevalence of low vision and blindness.

\begin{tabular}{lcc}
\hline Parameters & \multicolumn{2}{c}{ Classification } \\
\cline { 2 - 3 } Age group (in years) & Blindness $(\boldsymbol{n})$ & LV $(\boldsymbol{n})$ \\
$0-5$ & 10 & 1 \\
$6-10$ & 28 & 11 \\
$11-15$ & 62 & 15 \\
$16-20$ & 64 & 30 \\
$21-25$ & 24 & 6 \\
$26-30$ & 10 & 1 \\
$30+$ & 6 & - \\
Gender & & \\
Male & 117 & 40 \\
Female & 87 & 24 \\
\hline Total & $\mathbf{2 0 4}$ & $\mathbf{6 4}$ \\
\hline
\end{tabular}

LV, low vision. prevalence of low vision and blindness according to the participants' age and gender. Participants in the age group 16-20 years formed the majority in the prevalence of low vision and blindness.

\section{Classification of low vision and blindness}

Table 3 shows that $16.5 \%$ of the participants had moderate (0.52-1.00 $\log$ MAR) to profound (1.32-1.80 logMAR) low vision in the better eye. It was also noted that $66.4 \%$ of the participants were classified as having total blindness $(\mathrm{VA}=\mathrm{NPL})$. The rest $(17.2 \%)$ fell in the near-total blindness $(\mathrm{VA}<1.80 \log \mathrm{MAR})$ category according to the level of vision impairment.

\section{Causes of low vision and blindness}

The most common causes of low vision and blindness in this population were corneal opacities/phthisis bulbi (35.5\%), glaucoma $(25 \%)$, cataract $(13.4 \%)$, retinopathy $(10.8 \%)$ and complicated pseudophakia (8.2\%). Other causes are shown in Table 4.

\section{Association between age groups and causes of low vision and blindness}

Pearson chi-square tests were used to determine associations amongst the proportion of age groups and causes of low vision and blindness in the better eye. There was a statistically significant difference $(p<0.05)$ in the proportion of age groups (11-15 and 16-20) and cornea opacity/phthisis bulbi and age groups (6-10 and 30 years and older) and cataract as the cause of low vision and blindness in the better eye (Table 5). The remaining conditions showed no statistically significant difference $(p>0.05)$ in the

TABLE 3: Classification of low vision and blindness.

\begin{tabular}{|c|c|c|c|c|c|c|c|}
\hline \multirow[t]{3}{*}{ Distance VA } & \multirow{3}{*}{$\frac{\text { VA }}{\log M A R}$} & \multicolumn{4}{|c|}{ Gender } & \multicolumn{2}{|c|}{ Total } \\
\hline & & \multicolumn{2}{|c|}{ Male } & \multicolumn{2}{|c|}{ Female } & \multirow[t]{2}{*}{$n$} & \multirow[t]{2}{*}{$\%$} \\
\hline & & $n$ & $\%$ & $n$ & $\%$ & & \\
\hline Moderate low vision & $0.52-1.00$ & 1 & 0.4 & 3 & 1.1 & 4 & 1.5 \\
\hline Severe low vision & $1.02-1.30$ & 21 & 7.8 & 7 & 2.6 & 28 & 10.5 \\
\hline Profound low vision & $1.32-1.80$ & 7 & 2.6 & 5 & 1.9 & 12 & 4.5 \\
\hline Near-total blindness & $1.82-3.00$ & 26 & 9.7 & 20 & 7.5 & 46 & 17.2 \\
\hline Total blindness & 4.0 (NPL) & 102 & 38.1 & 76 & 28.4 & 178 & 66.4 \\
\hline Total & - & 157 & 58.6 & 111 & 41.4 & 268 & 100.0 \\
\hline
\end{tabular}

VA, visual acuity; NPL, no perception of light; logMAR, Logarithm of the Minimum Angle of Resolution.

\begin{tabular}{|c|c|c|c|c|c|c|}
\hline \multirow[t]{2}{*}{ Cause } & \multicolumn{2}{|c|}{ Blindness } & \multicolumn{2}{|c|}{ Low vision } & \multicolumn{2}{|c|}{ Total } \\
\hline & Male & Female & Male & Female & $n$ & $\%$ \\
\hline Cornea opacity/phthisis bulbi & 59 & 31 & 3 & 2 & 95 & 35.5 \\
\hline Glaucoma & 18 & 24 & 15 & 10 & 67 & 25.0 \\
\hline Cataract & 20 & 9 & 4 & 3 & 36 & 13.4 \\
\hline Retinopathy & 11 & 6 & 8 & 4 & 29 & 10.8 \\
\hline Complicated pseudophakia & 4 & 4 & 10 & 4 & 22 & 8.2 \\
\hline Optic atrophy & 1 & 10 & 0 & 1 & 12 & 4.5 \\
\hline Anophthalmos & 1 & 2 & - & - & 3 & 1.1 \\
\hline Unknown & 3 & 0 & - & - & 3 & 1.1 \\
\hline Trachoma & 0 & 1 & - & - & 1 & 0.4 \\
\hline Total & 117 & 87 & 40 & 24 & 268 & 100.0 \\
\hline
\end{tabular}


TABLE 5: Causes of low vision and blindness in the better eye according to age group.

\begin{tabular}{|c|c|c|c|c|c|c|c|c|}
\hline \multirow[t]{2}{*}{ Causes } & \multicolumn{7}{|c|}{ Age groups } & \multirow[t]{2}{*}{ Total } \\
\hline & $0-5$ & $6-10$ & 11-15 & $16-20$ & $21-25$ & $26-30$ & $30+$ & \\
\hline Cornea opacity/phthisis bulbi & $5 \dagger, \%$ & $15 \dagger$, & $35 \ddagger$ & $22 \dagger$ & $14 \dagger+$ & $3 \dagger, t$ & $1 \dagger, \dagger$ & 95 \\
\hline Glaucoma & $3 \dagger$ & $13 \dagger$ & $18 \dagger$ & $27 \dagger$ & $4 \dagger$ & $1 \dagger$ & $1 \dagger$ & 67 \\
\hline Cataract & $0 \dagger+$ & $2 \ddagger$ & $10 \dagger+$ & $14 \uparrow, \uparrow$ & $5 \dagger, \$$ & $2 \uparrow, \$$ & $3 \dagger$ & 36 \\
\hline Retinopathy & $2 \uparrow$ & $4 \dagger$ & $6 \dagger$ & $12 \dagger$ & $3 \dagger$ & $2 \dagger$ & $0 \dagger$ & 29 \\
\hline Complicated pseudophakia & $0 \dagger$ & $2 \dagger$ & $4 \dagger$ & $12 \dagger$ & $2 \dagger$ & $1 \dagger$ & $1 \dagger$ & 22 \\
\hline Optic atrophy & $1 \dagger$ & $2 \uparrow$ & $3 \dagger$ & $4 \dagger$ & $1 \dagger$ & $1 \dagger$ & $0 \dagger$ & 12 \\
\hline Anophthalmos & $0 \dagger$ & $1 \dagger$ & $1 \dagger$ & $1 \dagger$ & $0 \dagger$ & $0 \dagger$ & $0 \dagger$ & 3 \\
\hline Unknown & $0 \dagger$ & $0 \dagger$ & $0 \dagger$ & $1 \dagger$ & $1 \dagger$ & $1 \dagger$ & $0 \dagger$ & 3 \\
\hline Trachoma & $0 \dagger$ & $0 \dagger$ & $0 \dagger$ & $1 \dagger$ & $0 \dagger$ & $0 \dagger$ & $0 \dagger$ & 1 \\
\hline Total & 11 & 39 & 77 & 94 & 30 & 11 & 6 & 268 \\
\hline
\end{tabular}

$\dagger$, did not differ significantly amongst age groups; $\neq$, did not differ significantly amongst age groups.

TABLE 6: Association between the proportion of gender and causes of low vision and blindness.

\begin{tabular}{|c|c|c|c|c|c|c|}
\hline \multirow[t]{2}{*}{ Causes } & \multicolumn{2}{|c|}{ Blindness } & \multicolumn{2}{|c|}{ Low vision } & \multicolumn{2}{|c|}{ Total } \\
\hline & Male & Female & Male & Female & $n$ & $\%$ \\
\hline Cornea opacity/phthisis bulbi & $59 \dagger$ & $31 \%$ & $3 \S$ & $2 \S$ & 95 & 35.5 \\
\hline Glaucoma & $18 \dagger$ & $24 \dagger$ & $15 \S$ & $10 \S$ & 67 & 25 \\
\hline Cataract & $20 \dagger$ & $9 \dagger$ & $4 \S$ & $3 \S$ & 36 & 13.4 \\
\hline Retinopathy & $11 \dagger$ & $6 \dagger$ & $8 \S$ & $4 \S$ & 29 & 10.8 \\
\hline Complicated pseudophakia & $4 \dagger$ & $4 \dagger$ & $10 \S$ & $4 \S$ & 22 & 8.2 \\
\hline Anophthalmos & $1 \dagger$ & $2 \dagger$ & - & - & 3 & 1.1 \\
\hline Unknown & $3 \dagger$ & $0 \dagger$ & - & - & 3 & 1.1 \\
\hline Trachoma & $0 \dagger$ & $1 \dagger$ & - & - & 1 & 0.4 \\
\hline Total & 117 & 87 & 40 & 24 & 268 & 100 \\
\hline
\end{tabular}

Note: Each superscript symbol denotes a subset of gender whose column proportions do not differ significantly from each other at the 0.05 level.

$\dagger$, did not differ significantly amongst participants with blindness; $\$$, differed significantly amongst participants with blindness; $\S$, did not differ significantly amongst participants with low vision.

proportion of age groups and the causes of low vision and blindness in the better eye.

\section{Association between gender and causes of low vision and blindness}

Pearson chi-square tests were used to determine associations between the proportion of gender and causes of blindness and low vision in the better eye. There was no statistically significant difference $(p>0.05)$ in the proportion of gender and the causes of low vision. However, there was a statistically significant difference $(p<0.05)$ in the proportion of gender and the causes of blindness such as cornea opacity/phthisis bulbi, glaucoma and optic atrophy as shown in Table 6.

\section{Discussion}

This study determined the prevalence and causes of low vision and blindness at Akropong School for the Blind. The prevalence of low vision based on presenting VA was $23.9 \%$ and the major anatomical causes of low vision and blindness were corneal opacity/phthisis bulbi, followed by glaucoma and cataracts. These causes of low vision and blindness are mostly avoidable, which could be a reflection of the inadequacy of primary and secondary eye care services and a skewed eye health workforce distribution in the administrative regions of Ghana. ${ }^{10}$ To illustrate this skewed workforce distribution, there are 91 ophthalmologists representing an ophthalmologist to population ratio of 1:311 080 in the public sector in Ghana, which is not enough to adequately address the eye care needs of the country and does not meet the VISION 2020 target of 1 ophthalmologist per 250000 population. However, the proportion of the population served by the eye care workforce in the public sector is not known in Ghana. Also, the availability of primary eye care services in the public sector is limited with only $44 \%$ of the total optometric workforce employed in that sector. ${ }^{10}$ The leading ocular conditions in this study such as corneal ulceration, which lead to corneal opacity/phthisis bulbi, along with glaucoma are managed at the primary level by optometrists in Ghana. Surgical cases such as cataracts are referred to the secondary level for further management by ophthalmologists. Furthermore, $42 \%$ of public health facilities are equipped with basic eye care equipment and most of them at the district level lack specialised equipment. ${ }^{10}$ This could lead to difficulty in diagnosing and managing these conditions, which results in vision impairment and blindness at the primary level.

There were more males than females in this study, possibly reflecting the trend observed in many countries of Africa, where males have a generally higher chance of being sent to schools than their female counterparts., ${ }^{11,12,13}$ Cultural and tradition practices in Ghana give preference to males over females in education. ${ }^{14}$ The gender ratio in this study is slightly lower than the reported studies in other developing countries like Ethiopia ${ }^{11,12}$ (1.8:1) and India ${ }^{15}$ (1.7:1).

It is interesting to note that the number of participants examined in this study was higher compared to a previous 
study conducted at the same school by Akafo and Hagan, who reported that there were 129 registered participants in 1989, whilst a study conducted in 2003 reported that 199 learners were registered at the school. ${ }^{8}$ A previous study conducted at Wa Methodist School for the Blind examined 190 participants in $2014 .^{6}$ These results may indicate that over the years, parents and caregivers have become aware of visual impairment and blindness amongst their children and the need to offer these children an opportunity to be educated at the appropriate schools for the blind. ${ }^{16}$ This could also be indicative of the failures at the primary care levels to identify, diagnose comprehensively and appropriately manage these conditions because of inadequate specialised equipment at the district level, hence increasing the number of cases that go untreated and end up at these schools.

The mean age of the participants was $15.79 \pm 6.15$ years and 127 (47.4\%) participants were younger than 16 years. Late presentation to schools and the quest for vocational training might have led learners of age 30 and over being present in the school. These results are similar to those reported in Ethiopia, ${ }^{11,12}$ Nigeria $^{13}$ and Burundi. ${ }^{17}$ Poor academic performance because of limited braille educational materials and late start of school have been cited as contributing factors to adults admitted in Schools for the Blind in Africa. ${ }^{11,12}$ It has been reported that these learners experience academic challenges, which retards their progress. ${ }^{11,12}$ Other researchers ${ }^{11,17}$ have reported that learners, mostly those admitted to boarding schools, receive little or no support from their guardians, resulting in slow academic progress. In addition, there are limited career opportunities for persons with visual impairment post-basic schooling, which may be the reason that they remain in vocational schools into adulthood. ${ }^{18}$

A low vision prevalence rate of $43.7 \%$ was previously reported at the same school by Ntim-Amponsah and $\mathrm{Amoaku},{ }^{8}$ which is almost twice the rate found in the current study. The decrease in the prevalence rate of low vision might have resulted from the increased awareness of eye health amongst parents/guardians of the participants as well as the Ghanaian society at large. ${ }^{19}$ Improvement in socioeconomic development and health care could have also contributed to this result. ${ }^{20}$ There has also been a general increase in access to eye care services and corrective devices in Ghana. ${ }^{10}$ Furthermore, better screening protocols, developed for school entry based on previous findings, might have also influenced the prevalence of low vision amongst the learners and contributed to the integration of learners with low vision into mainstream schools. ${ }^{8,21}$

A similar study amongst learners in a School for the Blind in Nigeria reported a lower prevalence rate for low vision $(13.3 \%) .{ }^{13}$ This reduced prevalence rate was reported to be because of the advancement of primary eye care, especially ophthalmology and optometric practices in Nigeria. ${ }^{22}$ Ophthalmologists to population ratio in Nigeria is higher
(3.3 million) than the reported average ratio (2.2 million) for other sub-Saharan regions. ${ }^{22}$ This shows that increased ophthalmological services can reduce the prevalence of low vision and blindness.

The most common anatomical causes of low vision and blindness amongst the participants were consistent with reports from similar studies conducted over the years in Schools for the Blind in Ghana. ${ }^{6,78}$ In all of these studies, including the current study, corneal opacity/phthisis bulbi, cataract and glaucoma were the major causes of blindness and low vision. The findings in this study are also consistent with those of Okoye et al. ${ }^{13}$ and Onakpoya et al. ${ }^{23}$ who conducted their studies in Nigeria. Furthermore, in other parts of Africa, anatomical anomalies contributing to visual loss have been recorded as a corneal opacity/ phthisis bulbi followed by whole globe lesions and lensrelated disorders, amongst others. ${ }^{24}$ The major causes of low vision and blindness reported in African studies did not change appreciably from 1995 to $2009,{ }^{24}$ indicating no marked regional variations amongst learners in schools for the blind in many African countries. The regional findings support the need for an increase in primary eye care services and associated workforce in Africa as well as the need for an equitable distribution and promotion of these services.

In contrast to the above-mentioned African studies, in Brazil, Couto et al. ${ }^{25}$ reported the main causes of blindness to be retinopathy of prematurity $(21 \%)$, optic nerve atrophy (18\%) and congenital glaucoma (16\%). A review study of blindness and low vision in America and the Caribbean found the major causes of low vision to be cataract, retinopathy of prematurity, optic atrophy and glaucoma. ${ }^{26}$ The differences in the most common cause of blindness may be because of regional variations as a consequence of varying access to care, socioeconomic status and prevention measures for childhood diseases such as corneal opacity/ phthisis bulbi, cataract and glaucoma amongst others, which could be positively impacted upon by low cost and improved access to eye care services. In developing countries such as Ghana, the high cost and poor access to eye care services make avoidable eye diseases such as glaucoma and cataract very common, which is evident in this study. ${ }^{10,27}$

The proportion of participants with cornea opacity/phthisis bulbi and cataract differed significantly amongst age groups (Table 5). The reason for this difference could not be determined in this study. However, a high mortality rate of 53 per 1000 for children in Ghana might have contributed to the difference in proportion amongst the age groups. ${ }^{28}$ There is a high premature death amongst children with disabilities compared to those with no disabilities, which leads to fall out of learners as they progress in school. Participants younger than 11 years were less likely to have a cataract and complicated pseudophakia compared to those of age 11 years and older. This might be because of late 
presentation of participants with cataract for surgery ${ }^{27,29,30,31}$ and late complications from cataract surgeries such as posterior subcapsular opacities as a result of inadequate follow-ups. ${ }^{27,32,33}$ Also, glaucoma and corneal opacities were more prevalent amongst those between ages 11 and 20 years, possibly because of the progressive nature of glaucoma and being more active (therefore more exposed to corneal insults), respectively. In addition, conditions, such as measles, vitamin A deficiency and severe keratoconus, which can cause corneal insults, might have influenced these results.

A significant proportion of males were blind from cornea opacity/phthisis bulbi compared to females. The aetiology of ocular conditions was not within the scope of this study. However, studies in other parts of Africa have reported that males have a higher risk of corneal blindness than females. ${ }^{34,35}$ This is because of the incidence of cornea trauma amongst male children as a result of playing with pointed objects. ${ }^{34,35}$ Previous studies in Ghana did not report on the association of gender with leading causes of low vision and blindness. Also, a significant proportion of females were blind from glaucoma and optic atrophy compared to males. This finding is similar to studies on glaucoma, but there is no substantive evidence of gender predilection for glaucoma and optic atrophy. ${ }^{36,37}$

In summary, the prevalence of low vision in this study was low compared to previous studies. The main cause of low vision in this study was glaucoma and the most common anatomical cause of low vision and blindness was corneal opacity/phthisis bulbi. This information can be used to inform stakeholders in the healthcare system in Ghana to increase eye care services in this region to further minimise avoidable causes of low vision and blindness.

\section{Acknowledgements}

The authors are grateful to the African Vision Research Institute (AVRI), South Africa, for their support during the study period. This article was adapted from a Master of Optometry project from the University of KwaZulu-Natal, Durban, South Africa.

\section{Competing interests}

The authors declare that they have no financial or personal relationships that may have inappropriately influenced them in writing this article.

\section{Authors' contributions}

M.A.K., K.P.M., K.S.N., S.B.B-K. and P.G-P. contributed equally to the design and implementation of this research, to the analysis of the results and to the writing of this manuscript.

\section{Funding information}

This study was funded by the College of Health Sciences Masters/PhD scholarship programme, University of KwaZulu-Natal grant extension 3841.

\section{Data availability}

The authors confirm that data supporting the findings in this study are available within this article.

\section{Disclaimer}

The views and opinions expressed in this article are those of the authors and do not necessarily reflect the official policy or position of any affiliated agency of the authors.

\section{References}

1. American Optometric Association. Optometric clinical practice guideline: Care of the patient with visual impairment (Low vision rehabilitation) [homepage on the Internet]. 2007 [cited 2018 Feb 1]. Available from: https://www.aoa.org/AOA/ Internet]. 2007 [cited 2018 Feb 1]. Available from: https://www.aoa.org/AOA/ based $\% 20$ guidelines/Care $\% 20$ of $\% 20$ Patient $\% 20$ with $\% 20$ Visual $\% 20$ Impairment \%20\%28Low\%20Vision\%20Rehab\%29.pdf

2. Binns AM, Bunce C, Dickinson C, Harper R, Tudor-Edwards R. How effective is low vision service provision? A systematic review. Surv Ophthalmol. 2012;57(1):3465. https://doi.org/10.1016/j.survophthal.2011.06.006

3. Pararajasegaram R. Low vision care: The need to maximize visual potential. Community Eye Health J. 2004;17(49):1-2.

4. World Health Organization. Programme for the Prevention of Blindness and Deafness. Global Initiative for the Elimination of Avoidable Blindness. 2000. Available from: https://apps.who.int/iris/handle/10665/63748

5. Kumah EK, Wiafe B, Baffoe IO. Ghana national blindness and visual impairment study [homepage on the Internet]. 2017 [cited 2018 Feb 2]. Available from: https://www.iapb.org/wp-content/uploads/2020/09/Ghana-Study-BVIS 8_6_2017_-Final-edit.pdf

6. Huh GJ, Simon J, Prakalapakorn GS. Causes of childhood blindness in north Ghana: Results from a school survey in upper west region, Ghana, and review of the literature. Int Ophthalmol. 2018;38(4):1415-1423. https://doi.org/10.1007/ s10792-017-0600-9

7. Akafo SK, Hagan M. Causes of childhood blindness in southern Ghana - A blind school survey. Ghana Med J. 1990;24(2): 113-119.

8. Ntim-Amponsah $\mathrm{CT}$, Amoaku WMK. Childhood visual impairment and unmet low vision care in a school for the blind. Int Ophthalmol. 2008;28:317-323. https:// doi.org/10.1007/s10792-007-9134-x

9. Akrofi MM, Akanbang $A B B, A b d a l l a h ~ C K$. Dimensions of regional inequalities in Ghana: Assessing disparities in the distribution of basic infrastructure among northern and southern districts. Inter J Reg Dev. 2018:5(1):25-43. https://doi. org/10.5296/ijrd.v5i1.12293

10. Morny EKA, Boadi-Kusi SB, Ocansey S, Kyei S, Yeboah K, Mmaduagwu MA. Assessing the progress towards achieving 'VISION 2020: The right to sight' initiative in Ghana. J Environ Public Health. 2019;2019:3813298. https://doi. org/10.1155/2019/3813298

11. Tumwesigye C, Msukwa G, Njuguna M, Shilio B, Courtright $P$, Lewallen $S$. Inappropriate enrollment of children in schools for the visually impaired in east Africa. Ann Trop Paediatr. 2009;29(2):135-139. https://doi.org/10.1179/ 146532809X440752

12. Asferaw M, Woodruff G, Gilbert C. Causes of severe visual impairment and blindness in students in schools for the blind in northwest Ethiopia. Br Med J Glob Health. 2017;2(2):e000264. https://doi.org/10.1136/bmjgh-2016-000264

13. Okoye OI, Aghaji AE, Ikojo IN. Causes of visual loss at a school for the blind in Nigeria. Nig J Med. 2009;18(3):306-310. https://doi.org/10.4314/njm.v18i3.51198

14. Appiah DK. Information seeking behaviour of visually challenged students in public universities: A study of University of Ghana, Legon and University of Education, Winneba. Libr Philos Pract [serial online]. 2017 [cited 2020 May 21]:1507. Available from: http://digitalcommons.unl.edu/libphilprac/1507

15. Hornby SAJ, Adolph S, Gothwal VK, Gilbert CE, Dondana L, Foster A. Evaluation of children in six blind schools of Andhra Pradesh. Indian J Ophthalmol. 2000;48(3):195-200.

16. Ministry of Education. Education Sector Performance Report. Accra: Ministry of Education; 2013.

17. Ruhagaze $P$, Njuguna KK, Kandeke $L$, Courtright $P$. Blindness and severe visual impairment in pupils at schools for the blind in Burundi. Middle East Afr Ophthalmol. 2013;20(1):61-65. https://doi.org/10.4103/0974-9233.106390

18. Dogbe D, Avoke M, Yekple Y, Odumah L. Employment opportunities for the visually impaired in Ghana. Int J Educ Res. 2007;3(2):275-282.

19. Ofosu A, Osei I, Hagan M, Biekro L, Awedoba AK. Eye health knowledge and health-seeking behaviours in Ghana. Afr Vis Eye Health. 2018;77(1):a426. https:// doi.org/10.4102/aveh.v77i1.426

20. Lartey ST, Khanam R, Takahashi S. The impact of household wealth on child survival in Ghana. J Health Popul Nutr. 2016;35(1):38. https://doi.org/10.1186/ s41043-016-0074-9

21. Ntim-Amponsah CT. Childhood visual impairment and unmet low-vision care in blind school students in Ghana. US Ophthalmic Rev. 2012;5(1):11-13. https://doi. org/10.17925/USOR.2012.05.01.11 
22. Palmer JJ, Chinanayi F, Gilbert A, et al. Mapping human resources for eye health in 21 countries of sub-Saharan Africa: Current progress towards VISION 2020. Hum Resour Health. 2014;12:44. https://doi.org/10.1186/1478-4491-12-44

23. Onakpoya $\mathrm{OH}$, Adegbehingbe BO, Omotoye OJ, Adeoye $\mathrm{AO}$. Causes of blindness in a special education school. West Afr J Med. 2011;30(1):47-50. https://doi. org/10.4314/wajm.v30i1.69917

24. Njuguna M, Msukwa G, Shilio B, Tumwesigye C, Courtright P, Lewallen S. Causes of visual impairment and blindness in children in schools for the blind in eastern Africa: Changes in the last 14 years. Ophthalmic Epidemiol. 2009;16(3):151-155. https://doi.org/10.1080/09286580902738183

25. Couto Jr A, Goncalves de Oliveira LA. The main causes of blindness and low vision in school for the blind. Rev Bras Oftalmol. 2016;75(1);26-29. https://doi. org/10.5935/0034-7280.20160006

26. Munoz B, West SK. Blindness and visual impairment in Americas and Caribbean Br J Ophthalmol. 2002;86(5):498-504. https://doi.org/10.1136/bjo.86.5.498

27. Gogate $\mathrm{P}$, Kalua K, Courtright P. Blindness in childhood in developing countries: Time for a reassessment? PLoS Med. 2009;6(12):e1000177. https://doi.org/ 10.1371/journal.pmed.1000177

28. Ghana Statistical Service. Ghana multiple indicator cluster survey with an enhanced malaria module and biomarker, 2011. Accra, Ghana: Ghana Statistical Service. 2012. Available at: http://dhsprogram.com/pubs/pdf/FR262/FR262.pdf

29. Courtright $P$, Williams $T$, Gilbert $C$, et al. Measuring cataract surgical services in children: An example from Tanzania. Br J Ophthalmol. 2008;92(8):1031-1034. https://doi.org/10.1136/bjo.2007.136168
30. Khandekar R, Sudhan A, Jain BK, Shrivastav K, Sachan R. Paediatric cataract and surgery outcomes in central India: A hospital based study. Indian J Med Sci. 2007;61(1):15-22. https://doi.org/10.4103/0019-5359.29593

31. Mwende J, Bronsard A, Mosha M, Bowman R, Geneau R, Courtright P. Delay in presentation to hospital for surgery for congenital and developmental cataract in Tanzania. Br J Ophthalmol. 2005;89(11):1478-1482. https://doi.org/10.1136/ bjo.2005.074146

32. Eriksen JR, Bronsard A, Mosha M, Carmichael D, Hall AB, Courtright P. Predictors of poor follow up in children that had cataract surgery. Ophthalmic Epidemiol. 2006;13(4):237-243. https://doi.org/10.1080/09286580600672213

33. Kishiki E, Shirima S, Lewallen S, Courtright P. Improving post-operative follow up of children receiving surgery for congenital or developmental cataract in Africa. J Am Assoc Paediatr Ophthalmol Strabismus. 2009;13(3):280-282. https://doi.org/ 10.1016/j.jaapos.2008.12.002

34. Ashaye AO, Oluleye TS. Pattern of corneal opacity in Ibadan, Nigeria. Ann Afr Med. 2004;3(4):185-187.

35. Seidu MA, Bolutife AO, Ogundipe AO. Prevalence and determinants of corneal blindness in a semi-urban population of southwest Nigeria. Niger J Ophthalmol. 2017;25(1):18-27. https://doi.org/10.4103/njo.njo_34_16

36. Vajaranant TS, Nayak S, Wilensky JT, Joslin CE. Gender and glaucoma: What we know and what we need to know. Curr Opin Ophthalmol. 2010;21(2):91-99. https://doi.org/10.1097/ICU.0b013e3283360b7e

37. Mark HH. Gender differences in glaucoma and hypertension. Arch Ophthalmol. 2005;123(2):284. https://doi.org/10.1001/archopht.123.2.284-a 